\title{
Long-term population changes of high-bog avifauna in Latvia
}

\author{
Oskars Keišss $^{1 *}$, Jānis Ķuze ${ }^{2}$, Andris Dekants ${ }^{3}$ \\ ${ }^{1}$ Institute of Biology, University of Latvia, Miera 3, Salaspils LV-2169, Latvia \\ ${ }^{2}$ Latvian Fund for Nature, Vìlandes iela 3-7, Rīga LV-1010, Latvia \\ ${ }^{3}$ Latvian Ornithological Society/BirdLife Latvia, Skolas 3, Rīga LV-1010, Latvia \\ *Corresponding author, E-mail: oskars.keiss@lu.lv
}

\begin{abstract}
High bogs as habitat for birds have experienced dramatic changes due to peat extraction in Northern Europe. The methods of peat extraction have changed since the $19^{\text {th }}$ century. We classified bogs in three categories: (1) intact (no peat extraction); (2) old (renaturalized) peat extraction bogs; (3) bogs with active peat extraction. Old peat extraction sites have revegetated and naturalized, while extraction sites have little space for biodiversity. We studied bird population changes in Latvian bogs by analysing data from four national bird atlases: 1980 to 1984, 1985 to 1989, 2000 to 2004 and 2013 to 2017, as well from transect counts on 13 plots to assess quantitative changes over the years 2003 to 2014. Red Grouse Lagopus lagopus was not confirmed to be breeding in Latvia during the period of the study and has practically disappeared; it was observed in a single locality in Latvia. Steep declines within bog habitats in Latvia were observed for two species: Curlew Numenius arquata (bogs are the primary habitats for Curlew in Latvia) and European Cuckoo Cuculus canorus. Several bird species showed moderate declines in bogs over the study period e.g. Wood Sandpiper Tringa glareola, Common Crane Grus grus and Chaffinch Fringilla coelebs. One species (Skylark Alauda arvensis) showed a strong increase. There are considerable differences of avifauna due to peat extraction history.
\end{abstract}

Key words: bird population trends, raised bogs, Latvia.

\section{Introduction}

Wetlands historically have been endangered by humans by land use change to agriculture. In Europe currently less than $20 \%$ of original wetland area remains in original conditions (Verhoeven 2014). Large scale drainage of wetlands, including the whole territories of some lakes (Lake Dievinezers) occurred in Latvia during the $19^{\text {th }}$ century (e.g. Vikssne 1997). Threats to peatlands remained in the $20^{\text {th }}$ century and peaked in Latvia between 1960 and 1980, when extraction of peat in Latvia exceeded 4 million tons annually (Šnore 2004). Also during the Soviet occupation period in Latvia drainage was planned in all raised bogs with a peat layer of 2 to $3 \mathrm{~m}$, with the aim to increase land productivity (tree growth) and facilitate peat extraction (Nusbaums 2008).

Despite these plans, Latvia still has large relatively intact mire tracts that represent European Union Protected Habitats (Auniňs 2013). However most of the small mires in Latvia have been subject to direct or indirect influence of drainage during various periods of history: most of the drainage events in wetlands have occurred in the past, but the effects of drainage are visible after a time lag (Nusbaums 2008). In comparison, Spain has lost $60 \%$ of its wetlands in the second half of the $20^{\text {th }}$ century, with small wetlands being the most affected ones (Gallego-Fernandez et al. 1999).

Here we present data on avifauna of only one specific mire habitat types - raised or ombrotrophic bogs. We try to determine causes of raised bog bird population change by examining changes in range fluctuations and trends in Latvia since 1980, when the first quantitative data exist.

\section{Methods}

\section{Bird distribution data}

Recent distribution changes of the bird populations in Latvian bogs were assessed by analysing data from four national bird atlases: First Latvian Breeding Bird Atlas 1980 - 1984 (Priednieks et al.); data collected for the first European Breeding Bird Atlas 1985 - 1989 (Latvian Ornithological society, unpublished data), Second Latvian Breeding bird Atlas 2000 - 2004 (Latvian Ornithological society, unpublished data) and the second European Breeding Bird Atlas 2013 - 2017 (Latvian Ornithological society, unpublished data).

During the first and second atlas data collection period (1980 to 1984, 1985 to 1989), the territory of Latvia was divided in $10 \times 10 \mathrm{~km}$ Universal Transversal Mercator projection squares $(n=739)$. Birds were recorded in $5 \times 5$ 
$\mathrm{km}$ squares (according to transversal Mercator projection TM-1993 with Baltic coordinates, total $\mathrm{n}=2785$ ) during the third and fourth periods.

For comparison of all four periods, the $5 \times 5 \mathrm{~km}$ squares used during 2000 to 2004 and 2013 to 2017 (TM-1993 5 $\times 5 \mathrm{~km}$ squares) were merged into $10 \times 10 \mathrm{~km}$ squares ( $\mathrm{n}$ $=740$ ). Data from the $10 \times 10 \mathrm{~km}$ squares were used for comparison of distributional data from the first, second and third, fourth atlas periods, assuming that number of squares were equal (739 vs. 740 ).

Bird breeding probability in a square was scored by using 17 categories in four classes (standard for atlas studies, see Hagemeijer, Blair 1997) to categorize observations: (1) presence of the species; (2) possible breeding; (3) probable breeding and (4) confirmed breeding.

The categories were identical to those used in all four atlas periods of Latvia. For comparing distributions in the study periods, it is important to evaluate coverage of the territory. One of the indicators of the coverage might be the number of squares where have been no observations, i.e. the number of not studied squares. In the first Latvian National atlas (1980 to 1984) $5.1 \%$ of all squares remained unstudied (Priednieks et al. 1989), but in the period of 2000 to 2004 only $1.9 \%$ and 2013 to $20172.1 \%$. Thus in the period of the second National atlas, the territory was better covered.

\section{Bird surveys}

Bird census data were collected in a $4.91 \mathrm{~km}$ long census transect in Kemeri bog (beginning of the transect at $\left.56^{\circ} 54^{\prime} 28^{\prime \prime} \mathrm{N} ; 23^{\circ} 29^{\prime} 31^{\prime \prime} \mathrm{E}\right)$. The Kemeri raised bog covers 6192 ha and is part of the Kemeri National park in Central Latvia. Bird surveys were carried out twice per season (in mid May and mid June) in the period of 2003 to 2014. Bird counts were done by modified Finnish Line-transect method (Järvinen, Väisänen 1975) with a $50 \mathrm{~m}$ main belt, conducted by the same observer during the whole study period. The counts started within one hour after sunrise and were continued for approximately 3 to $4 \mathrm{~h}$.

Bird surveys by breeding bird atlas methods were carried out in three raised bogs in 2014 and 2015: Orlova

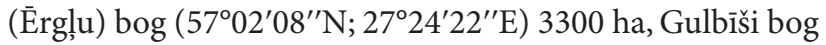
$\left(57^{\circ} 10^{\prime} 26^{\prime \prime} \mathrm{N} ; 26^{\circ} 50^{\prime} 33^{\prime \prime} \mathrm{E}\right) 260$ ha in Eastern part of Latvia and Dunika (Tīrspurvs) bog (56 $\left.16^{\prime} 31^{\prime \prime} \mathrm{N} ; 21^{\circ} 22^{\prime} 43^{\prime \prime} \mathrm{E}\right)$ 1807 ha in Southwestern part of Latvia. Dunika and Orlova are relatively intact bogs, while Gulbǐš has an old peat extraction site; therefore the bog has been drained and pine stands have greatly reduced the open raised bog area

\section{Analysis of survey data}

TRends and Indices for Monitoring data (TRIM) version 3 software (Pannekoek, van Strien 2001) was used for analysis of bird count data. Statistics Netherlands has developed this program specifically for analyses of bird monitoring data and it is recommended by the European Bird Census Council (Gregory et al. 2005).

TRIM calculates the annual index for species by using data rows from various observation points (sample plots). The data rows must overlap. TRIM is based on the principles of Poisson distribution (log linear models) and the basic model is described as follows:

$$
\ln \mu_{i j}=\alpha_{i}+\gamma_{j}
$$

where $\alpha_{i}$ is the effect of site, and $\gamma_{j}$ is effect of the year on the natural logarithm of the expected count value of $\mu_{i j}$.

\section{Results}

According to our analyses (Table 1) only range of two characteristic raised bog species expanded in Latvia since 1980: Greenshank (Tringa nebularia) and Great Grey Shrike (Lanius excubitor). The distribution range one species, Whimbrel (Numenius phaeopus) has not significantly changed (Table 1). Two species were lost as breeding birds: Black-throated Diver (Gavia arctica) and Willow Grouse (Lagopus lagopus). The breeding range of three selected species, Curlew (Numenius arquata), Golden Plover (Pluvialis apricaria) and Wood Sandpiper (Tringa glareola) significantly decreased, especially between the last two periods: 2000 to 2004 and 2013 to 2017 (Table 1).

Table 1. Registered squares of $10 \times 10 \mathrm{~km}$ Universal Transversal Mercator grid in Latvia for selected mire species during the three Latvian breeding bird atlas studies in 1980 - 1984; 1985 - 1989, 2000 - 2004 and 2013 - 2017. PS, possible breeding; PR, probable breeding; CF, confirmed breeding

\begin{tabular}{|c|c|c|c|c|c|c|c|c|c|c|c|c|c|c|c|c|c|c|}
\hline \multirow[t]{3}{*}{ No. } & \multirow[t]{3}{*}{ Species } & \multicolumn{16}{|c|}{ Number of atlas squares $10 \times 10 \mathrm{~km}$} & \multirow{3}{*}{$\begin{array}{c}\text { Range } \\
\text { estimate in } \\
\text { Latvia }\end{array}$} \\
\hline & & \multicolumn{4}{|c|}{$1980-1984$} & \multicolumn{4}{|c|}{$1985-1989$} & \multicolumn{4}{|c|}{$2000-2004$} & \multicolumn{4}{|c|}{$2013-2017$} & \\
\hline & & PS & PR & CF & Total & PS & PR & $\mathrm{CF}$ & Total & PS & PR & CF & Total & PS & PR & CF & Total & \\
\hline 1 & Gavia arctica & 2 & 7 & 2 & 11 & 3 & 4 & 1 & 8 & 3 & 0 & 0 & 3 & 1 & 0 & 0 & 1 & contracting \\
\hline 2 & Numenius arquata & 26 & 51 & 15 & 92 & 17 & 28 & 17 & 62 & 53 & 32 & 9 & 94 & 36 & 18 & 2 & 56 & contracting \\
\hline 3 & Numenius phaeopus & 2 & 5 & 3 & 10 & 2 & 6 & 8 & 16 & 8 & 14 & 4 & 26 & 9 & 4 & 3 & 16 & stable \\
\hline 4 & Tringa glareola & 44 & 38 & 23 & 105 & 21 & 18 & 24 & 63 & 34 & 36 & 32 & 102 & 21 & 23 & 13 & 57 & contracting \\
\hline 5 & Tringa nebularia & 0 & 1 & 0 & 1 & 1 & 0 & 0 & 1 & 4 & 4 & 1 & 9 & 9 & 3 & 0 & 12 & expanding \\
\hline 6 & Pluvialis apricaria & 12 & 44 & 29 & 85 & 6 & 27 & 22 & 55 & 16 & 40 & 14 & 70 & 15 & 25 & 9 & 49 & contracting \\
\hline 7 & Lagopus lagopus & 3 & 4 & 0 & 7 & 1 & 0 & 0 & 1 & 2 & 0 & 0 & 2 & 1 & 0 & 0 & 1 & contracting \\
\hline 8 & Lanius excubitor & 15 & 7 & 15 & 37 & 13 & 4 & 10 & 27 & 44 & 14 & 20 & 78 & 80 & 27 & 43 & 150 & expanding \\
\hline
\end{tabular}


Table 2. Trends of the bird populations at Kemeri Bog for the period $2003-2014$, slope model characterized by TRIM recommendations (Pannekoek, van Strien 2001). ${ }^{\star} p<0.05 ;{ }^{* *} p<0.01$

\begin{tabular}{|c|c|c|c|c|}
\hline No. & Species & Slope & SE & Overall slope model \\
\hline 1 & Curlew Numenius arquata & 0.8025 & 0.0446 & steep decline $e^{\star \star}$ \\
\hline 2 & Cuckoo Cuculus canorus & 0.8427 & 0.0392 & steep decline $e^{\star \star}$ \\
\hline 3 & Common Crane Grus grus & 0.9179 & 0.0355 & moderate decline* \\
\hline 4 & Chaffinch Fringilla coelebs & 0.9257 & 0.0250 & moderate decline $e^{\star *}$ \\
\hline 5 & Wood Sandpiper Tringa glareola & 0.9389 & 0.0237 & moderate decline $e^{* *}$ \\
\hline 6 & Black Grouse Tetrao tetrix & 0.9439 & 0.0663 & uncertain \\
\hline 7 & Golden Plover Pluvialis apricaria & 0.9495 & 0.0313 & uncertain \\
\hline 8 & Lapwing Vanellus vanellus & 0.9703 & 0.0372 & uncertain \\
\hline 9 & Common Gull Larus canus & 0.9956 & 0.0654 & uncertain \\
\hline 10 & Tree Pipit Anthus trivialis & 1.0051 & 0.0177 & stable \\
\hline 11 & Skylark Alauda arvensis & 1.1600 & 0.0329 & strong increase $\mathrm{e}^{\star \star}$ \\
\hline
\end{tabular}

The range expansion expansion of Great Grey Shrike was associated with increased areas of its alternative habitat, young forest stands, and was not due to increase of the Great Grey Shrike population in raised bogs. Thus, the only true raised bog species which experienced range expansion was Greenshank, but this species as a breeder was still very rare (Table 1). Both of the true raised bog species (Blackthroated Diver and Willow Grouse) were practically extinct as breeders in Latvia. It is most likely that the causes of Willow Grouse extinction in Latvia are climate change with increasingly shorter snow coverage.

The quantitative annual trends (Table 2) were generated only for one raised bog (Ķemeri bog). However, given that it is one of the largest and most important bogs for biodiversity in Latvia, the trends are important indicators for populations of those species. There were two bird species with steep and significant declines in Kemeri bog: Curlew (Numenius arquata) and Cuckoo (Cuculus canorus). The Latvian national monitoring data on Cuckoo are contradictory, as this data shows a stable trend since 2005 (Auninšs 2018). Thus the observed steep decline in Kemeri bog is due to local unknown cause. Curlew does lack sufficient data in the Latvian National monitoring scheme (Auniņš 2018); therefore, the steep decline in Kemeri bog should be taken as very serious signal for conservation needs of this species in Latvia. Additionally, Curlew does show a contraction of range in Latvia (Table 1).

Among three species showing a moderate decline, data for Chaffinch is contradicting with the stable trend in Latvia as a whole in the Latvian national monitoring (Auniņš2018). Common Crane shows an increase in Latvian National monitoring scheme, mostly due to expansion of breeding habitat into wet forest areas (Auniņš 2018), and Wood Sandpiper lacks data in the Latvian National monitoring

Table 3. Breeding presence/absence on 17 selected bird species at three raised bog study sites in Latvia in 2014 and 2015

\begin{tabular}{|c|c|c|c|c|}
\hline No. & Species & Orlova & Dunika & Gulbīši \\
\hline 1 & Black-throated Diver Gavia arctica & - & - & - \\
\hline 2 & Wigeon Anas penelope & - & + & - \\
\hline 3 & Willow Grouse Lagopus lagopus & - & - & - \\
\hline 4 & Black Grouse Tetrao tetrix & + & + & - \\
\hline 5 & Common Crane Grus grus & + & + & + \\
\hline 6 & Golden Plover Pluvialis apricaria & + & + & - \\
\hline 7 & Lapwing Vanellus vanellus & + & + & - \\
\hline 8 & Whimbrel Numenius phaeopus & + & - & - \\
\hline 9 & Curlew Numenius arquata & + & - & - \\
\hline 10 & Greenshank Tringa nebularia & - & - & - \\
\hline 11 & Wood Sandpiper Tringa glareola & + & + & - \\
\hline 12 & Common Gull Larus canus & + & + & - \\
\hline 13 & Cuckoo Cuculus canorus & + & + & + \\
\hline 14 & Skylark Alauda arvensis & + & + & - \\
\hline 15 & Tree Pipit Anthus trivialis & + & + & + \\
\hline 16 & Great Grey Shrike Lanius excubitor & + & + & - \\
\hline \multirow[t]{2}{*}{17} & Chaffinch Fringilla coelebs & + & + & + \\
\hline & Number of species & 13 & 12 & 4 \\
\hline
\end{tabular}


scheme (Auniňš 2015; 2018). The Wood Sandpiper decline in Kemeri bog is important, since it indicates that more attention should be paid to the conservation needs of this species in Latvia; additionally, Wood Sandpiper show range contraction in Latvia (Table 1).

Skylark (Alauda arvensis) was the only of our study species with strong increase in Kemeri bog. The national trend of this species since both 1995 and 2005 is decreasing in Latvia as a whole (Auniňs 2018). The observed trend might well be explained by the increase of intensive agricultural methods in Latvia, especially in the Central Latvia where Kemeri bog is located. Skylarks might be colonising the bog areas to escape industrial agricultural lands where breeding has become impossible.

The breeding avifauna of the three selected bog sites (Table 3) indicate that the two natural bogs (Orlova and Dunika) with open raised bog landscape had higher number of raised bog species, while Gulbǐš bog with a small open raised bog area had none of the typical bog bird species as breeders (except for Common Crane, which also inhabits wet forests in Latvia). The overgrowth of open bog areas as a consequence of drainage is the greatest challenge for conservation of biodiversity in raised bog in Latvia.

\section{Discussion}

The estimated loss of European wetlands up to the year 2000 reached $80 \%$ of the original area; peat extraction occurred as early as the $11^{\text {th }}$ and $12^{\text {th }}$ century in the Netherlands (Borger 1992 after Verhoeven 2014). Threats to bogs in Northern Europe originate from human disturbance due to drainage of bogs (Fraixedas et al. 2017) for peat extraction and also of surrounding agricultural lands; a minor role is played by climate warming (e.g. Luoto et al. 2004).

A larger study of bird populations of raised bog in the Northern Baltic Region (Finland, Sweden, Estonia and Latvia) showed general decline of $40 \%$ in Northern European peatland bird population sizes from 1981 to 2014 with the decline being more pronounced in Sweden and Finland (Fraixedas et al. 2017). In Latvia decline of bog bird species started early before 1980ies. Vilks (1943) described Willow Grouse as a locally common bird species in Eastern Latvia in the beginning of the $20^{\text {th }}$ century. While climate change might have influenced the decline in this species during the last 50 years, were early stages of decline 100 years ago, is most likely due to to drainage, causing loss of habitat by afforestation. The dry areas of drained bog become suitable for growth of low productivity pine forest. Forest edge is known to negatively affect bog bird species like Willow Grouse (Hancock et al. 2009). The forest edge zone includes an entire patch of open area in old (re-naturalized) peat extraction bogs like Gulbišu bog, explaining the low richness of bird fauna, and lack of high bog bird species (except Common Crane) that breed.

In comparison to Fennoscandian populations, the Baltic peatland bird species ar much more poorly monitored (Fraixedas et al. 2017), but given the fact that the populations in Estonia and Latvia are still performing relatively better than in Sweden and Finland (Fraixedas et al. 2017), it is very important to make decisions on protection and management favourable for bird populations and bog protection, restricting peat extraction to only already degraded bogs, but prohibiting peat extraction in new, intact bogs. We strongly suggest to restart the state peatland bird monitoring, active in Latvia in early 2003 and 2004 (L. Salmina unpublished data), but discontinued later.

\section{Acknowledgements}

This work was supported by European Social Fund (ESF) within the Project "New interdisciplinary group of scientists for resource exploration sustainable and use and protection of Latvian bogs" Nr. 2014/0009/1DP/1.1.1.2.0/13/APIA/VIAA/044 to the Institute of Biology, University of Latvia. We kindly acknowledge Dr. Viesturs Kerus for permission to use unpublished atlas data of the Latvian Ornithologcal Society. We also acknowledge all volunteers gathering breeding bird atlas data in Latvia.

\section{References}

Auniņš A. (ed) 2013. European Union Protected Habitats in Latvia: Interpretation Manual. Latvian Fund for Nature, Ministry of Environmental Protection and Regional Development, Riga, 320 pp.

Auniņš A. 2015. Breeding bird census in Latvia: population changes in common birds 2005-2014. Putni dabā 69: 8-15. I in Latvian/

Auninsš A. 2018. Declines in populations of breeding birds continue: the species wintering in sub-Saharan Africa and farmland birds most affected. Putni dabā 81: 10-15. /in Latvian/

Fraixedas S., Lindén A., Meller K., Lindström Å., Keišs O., Kålås J.A., Husby M., Leivits, A., Leivits M., Lehikoinen A. 2017. Substantial decline of Northern European peatland bird populations: Consequences of drainage. Biol. Conserv. 214: 223-232.

Gallego-Fernandez J. B., Garcia-Mora M. R., Garcia-Novo F. 1999. Small wetlands lost: a biological conservation hazard in Mediterranean landscapes. Environ. Conserv. 26: 190-199.

Hagemeijer W.J., Blair M.J. (eds) 1997. The EBCC Atlas of European Breeding Birds: their Distribution and Abundance. Poyser, London.

Hancock M.H., Grant M.C., Wilson J.D. 2009. Associations between distance to forest and spatial and temporal variation in abundance of key peatland breeding bird species. Bird Study 56: 53-64.

Järvinen O., Väisänen R.A. 1975. Estimating relative densities of breeding birds by the line transect method. Oikos 26: 316-322.

Luoto M., Heikkinen R.K., Carter T.R. 2004. Loss of palsa mires in Europe and biological consequences. Environ. Conserv. 31 : $30-37$.

Nusbaums J. 2008. Preventing drainage influence in the raised bogs. In Pakalne M. (ed) Mire Conservation and Management in Especially Protected Nature Areas in Latvia. Latvian Fund for Nature, Rīga, pp. 119-131. 
Pannekoek J., van Strien A.J. 2001. TRIM 3 manual: TRends and Indices for Monitoring data. Research paper No. 0102. Statistics Netherlands, Voorburg, 58 p.

Priednieks J., Strazds M., Strazds A., Petrinš A., Vīksne J. (eds) 1989. Latvian Breeding Bird Atlas 1980-1984. Zinātne, Rīga. $352 \mathrm{p}$.

Šņore A. 2004. Peat in Latvia. Latvijas Kūdras ražotāju asociācija,
Rīga, 64 p. /in Latvian/

Verhoeven J.T. 2014. Wetlands in Europe: perspectives for restoration of a lost paradise. Ecol. Eng. 66: 6-9.

Vìksne J. 1997. The bird Lake Engure. Jāna Sēta, Rīga. 111 p.

Vilks K. 1943. Avifauna aus vier Gegenden Lettlands. Folia Zoologica et Hydrobiologica 12: 247-265. 